\title{
PENCATATAN PERKAWINAN DALAM HUKUM KEKELUARGAAN DI INDONESIA DAN RELEVANSINYA DENGAN TEORI MASLAHAH AL-SYATIBI
}

\author{
Yanti Rosalina Naitboho \\ Universitas Muhammadiyah Kupang \\ yantirosalina02@gmail.com
}

\section{Abstrak}

Persoalan pencatan perkawinan sebagai syarat sah perkawinan merupakan persoalan yang sampai saat ini masih diperdebatkan. Menurut sebagian pandangan, pencatatan tidak merupakan syarat sah perkawinan karena dalam perkawinan telah ada saksi yang kedudukannya sebagai bukti bila mana suatu hari terjadi perselisihan antara suami dan istri. Sedangkan perlindungan lainnya mengnggap bahwa kedudukan pencatatan perkawinan dapat dijadikan sebagai syarat sah perkawinan. Tarik ulur perdebatan-perdebatan tersebut berlanjut dalam pembahasan pengesahan RUU hukum materil Peradilan Agama di Parlemen. Bila hal ini dibiarkan berlarut-larut dalam arus perdebatan, maka kedudukan pencatatan perkawinan tidak akan menmukan titik terang. Perdebatanperdebatan tersebut pada akhirnya berimplikasi pada perilaku hukum di masyarakat terhadap pencatatan perkawinan. Bagi sebagian masyarakat, perkawinan tidak perlu dicatatkan. Sebab dicatat atau tidaknya perkawinan tdak berdampak pada status perkawinan mereka. Karena sejatinya menurut hukum Islam, perkawinan adalah sah manakala telah memenuhi rukun dan syarat sah 
perkawinan sedangkan sebagian masyarakat lainnya, pencatatan perlu dilakukan agar ada kapastian hukum dalam ikatan perkawinan. Kapastian hukum yang dimaksud adalah adanya jaminan dari Negara dimana di kemudian hari terjadi perselisihan antara suami dan istri. Perlunya pencatatan perkawinan adalah sebagai upaya untuk lebih mempertegas bagaimana posisi pembuktian suatu suatu perkawinan. Hal ini lebih menarik lagi bila dikaitkan dengan teori maslahah Al-Syatibi. Berdasarkan uraian di atas, maka penelitian ini mencoba untuk menelaah apakah pencatatan perkawinan harus menjadi salah satu syarat sah perkawinan atau tidak dan bagaimana relevansi pencatatan perkawinan tersebut dengan teori maslahah AlSyatibi. Untuk dapat mengungkap pertanyaan-pertanyaan tersebut, maka dilakukan dilakukan penelitian dengan menggunakan metode penelitian normatif yaitu penelitan hukum yang dilakukan dengan cara meneliti bahan pustaka atau data sumber.

\section{Keyword: Pencatatan Perkawinan, Hukum Kekeluargaan, Teori Maslahah Al-Syatibi}

\section{Abstract}

The issue of marriage painting as a legitimate requirement for marriage is a problem that is still debated to date. According to some views, recording is not a legitimate requirement for marriage because in a marriage there have been witnesses whose position as evidence if there is a dispute between a husband and wife one day. Whereas other protections suggest that the position of marriage registration can be used as a legitimate requirement for marriage. The tug of war debates continued in the discussion of ratification of the material law on the Religious Courts in Parliament. If this is allowed to drag on in the flow of debate, then the position of 
recording the marriage will not show a bright spot. These debates ultimately have implications for legal behavior in the community towards marriage registration. For some people, marriage does not need to be listed. Because whether or not marriage is recorded does not affect their marital status. Because in reality according to Islamic law, marriage is legal when it has fulfilled the pillars and legal requirements of marriage, while some other communities, registration needs to be done so that there is legal certainty in the marriage bond. The legal certainty referred to is the existence of guarantees from the State where in the future there will be disputes between husband and wife. The need for marriage registration is an attempt to further emphasize the position of proof of a marriage. This is even more interesting when it is associated with the theory of Maslahah Al-Syatibi. Based on the description above, this study tries to examine whether marriage registration must be one of the legitimate requirements of marriage or not and how the relevance of recording the marriage is the theory of maslahah Al-Syatibi. To be able to reveal these questions, the research was conducted using normative research methods, namely legal research carried out by examining library materials or source data.

\section{Keywords: Marriage Registration, Family Law, Maslahah Al- Syatibi Theory}

\section{A. Latar Belakang}

Perkawinan dan segala aspek yang timbul darinya dapat ditemukan dalam undang-undang nomor 1 tahun 1974 tentang perkawinan. Diaturnya perkawinan melalui undang-undang tersebut adalah sebagai bentuk upaya protektif atau perlindungan hukum. Lebih lanjut, perlindungan tersebut merupakan kewajiban Negara yang berdasarkan hukum (pasal 1 ayat 3 undang-undang dasar 1945. Karena setiap perilaku 
atau perbuatan warga Negara harus dilaksanakan berdasarkan dan tunduk pada peraturan perundang-undangan yang berlaku.

Selain perlindungan, kodifikasi hukum perkawinan dalam peraturan perundang-undangan juga dimaksudkan untuk menciptakan ketertiban dan keadilan dalam perkawinan (Peter Mahmud, 2010:58). Dimana ketertiban menunjuk pada hubungan atau komunikasi zahiriah atau dengan kata lain ia melihat pada proses interaksi para pribadi dalam kelompok dan kadilan lahir sebagai akibat dari pelaksanaan kewajiban dan pemenuhan hak-hak sehingga tercipta keluarga sakinah, mawaddah warrahmah (Purnadi Purba Cakra, 1993:20). Namun realitasnya undang-undang tersebut tidak terimplementasikan atau terlaksana dengan baik. Masih banyak penyimpanganpenyimpangan hukum yang dilakukan masyarakat. Dalam beberapa kasus misalnya perkawinan tidak dicatatkan masih sering ditemukan dalam masyarakat.

Perkawinan semacam ini sangat merugikan terutama bagi perempuan. Padahal jika diperhatikan makna dari perkawinan itu sendiri adalah ikatan yang kuat antara seorang perempuan atau seorang laki-laki yang tidak hanya disaksikan dua orang saksi atau manusia saja melainkan disaksiakan oleh Allah Swt. (Amir Syarifudin, 2009:62). Oleh karena itu, dengan menaati peraturan perundang-undangan ini berarti masyarakat didorong untuk mewujudkan perkawinan. Dari sekian banyak norma tentang pencatatan perkawinan merupakan norma yang multi tafsir. Apakah pencatatan tersebut sebagai rukun perkawinan atau sebagai syarat administrasi saja. Norma hukum perkawinan tentu memiliki tujuan yakni untuk melindungi kepentingan-kepentingan yang ada dalam masyarakat, baik kepentingan pribadi, kepentingan anak, kepentingan publik maupun sosial. Namun karena norma ini tidak dipatuhi dan dilaksanakan olek subyek hukum, maka cita 
hukum sebagaimana yang diinginkan oleh undang-undang tidak tercapai. Banyaknya perkawinan dilakukan di bawah tangan atau perkawinan tidak dicatatkan, mengidentifikasi bahwa undang-undang tersebut tidak berlaku secara efektif. Sebagai contoh seprti kasus perkawinan di bawah tangan Aceng H.M Fikri yang saat itu sebagai bupati Garut dengan Fani Octara yang berlaangsung singkat. Di mana perkawinan tersebut hanya bertahan hingga 4 hari saja dan hubungan perkawinan mereka putus.

Al-Qur'an dan hadits tidak mengatur secara rinci mengenai pencatatan perkawinan. Namun dirasakan oleh masyarakat mengenai pentingnya pencatatan nikah, sehingga diatur melalui Perundang-Uundangan baik Undang-Undang No. 1 Tahun 1974 Tentang Perkawinan maupun Komilasi Hukum Islam. (Zainuddin Ali, 2006:26). Kemudian seiring dengan perkembangan zaman, hal ini dirasakan sangat penting bagi masyarakat. Sehubungan dengan itu, Al-Syatibi mengatakan bahwa syariah telah memandang kebaikan hukukm dan apa yang dipandang baik dalam pengalaman social. Artinya jika kita tetap berpegang teguh pada pemahaman perkawinan tradisional yang tidak menganggap perkawinan sebagai sesuatu yang urgen, maka akan semakin banyak timbul persoalan-persoalan dalam perkawinan. Misalnya tidak dapat melakukan tuntutan atas hak nafkah si pengadilan karena tidak memilki bikti perkawinan. Dari itu, kemudian pencatatan perkawinan memiliki kedudukan yang penting jika ditinjau perspektif maqasid al-Syariah dengan tujuan agar mewujudkan kemaslahatan dalam perkawinan (Muhammad Khalid Masud, 2996:236).

Berdasarkan urain di atas, maka sangat diperlukan untuk dilakukan pengkajian dan penelitian terhada pencatatan perkawinan dalam bentuk karya ilmiah.

Sangaji Jurnal Pemikiran Syariah dan Hukum 


\section{B. Tujuan}

Tujuan yang dicapai dalam penelitian ini adalah untuk mengetahui apakah pencatatan perkawinan harus dijadikan salah satu syarat sahnya perkawinan menurut hukum islam atau tidak dan untuk mengetahui relevansi pencatatan perkawinan yang dinalisis menggunakan teori maslahah AlSyatibi.

\section{Metode}

Penelitian hukum normatif (normative law research) menggunakan studi kasus normatif berupa produk perilaku hukum, misalnya mengkaji undang-undang. Pokok kajiannya adalah hukum yang dikonsepkan sebagai norma atau kaidah yang belaku dalam masyarakat dan menjadi acuan perilaku setiap orang. Sehingga penelitian hukum normatif berfokus pada inventarisasi hukum positif,asas-asas dan doktrin hukum, penemuan hukum dalam perkara in concreto, sistematik hukum, taraf sinkronisasi, perbandingan hukum dan sejarah hukum (Abdulkadir Muhammad. 2004: 52).

Mengingat permaslahan dalam penelitian ini di fokuskan pada pencatatan perkawinan dan relevensinya dengan teori maslahah Al-Syatibi, maka pendekatan yang digunakan adalah pendekatan yuridis nornatif. Karena itu, tipe penelitian yang dipakai dalam penelitian ini adalah tipe penelitian deskriptif, yaitu penelitian untuk memecahkan masalah yang ada pada masa sekarang dengan mengumpulkan data, menyusun, mengklasifikasikan, menganalisis dan menginterpretasikan.

\section{Hasil dan Pembahasan}

Perkawinan atau pernikahan adalah perjanjian kesepakan 2 orang calon suami istri untuk hidup bersama dan saling memberi, yang diucapkan melalui ijab qabul antara wali 
perempuan dengan calon suami oleh dua orang saksi yang adil. Di dalam ajaran agama Islam, perkawinan merupakan sunnah Nabi Muhammad Saw. (Ahmad Rajafi, 2015:151).

Sahnya perkawinan bagi orang Islam di Indonesia, menurut pasal 2 RUU Perkawinan tahun 1973, di tentukan berdasarkan "Pencatatan Perkawinan" sebagai unsur penentu. Hukum Agama (Islam) dapat diberlakukan sepanjang tidak bertentangan dengan Undang-Undang ini yang berfungsi sebagai Pelengkap, bukan penentu. RUU Perkawinan Tahun 1973 merumuskan sahnya perkawinan dalam pasal 2 ayat 1 sebagai berikut: "perkawinan adalah sah apabila dilakukan di hadapan pegawai pencatatan perkawinan, dicatatkan dalam daftar pencatatan perkawinan oleh pegawai tersebut dan dilangsungkan menurut ketentuan undang-undang ini atau ketentuan hukum perkawinan pihak-pihak yang melakukan perkawinan, sepanjang tidak bertentangan dengan UndangUndang ini (Neng Djubaedah, 2010:207) .

Dalam konteks Al-Qur'an telah menetapkannya dalam perkara muamalah, namun perlu disebutkan disini, bahwa ketika Indonesia belum merdeka dan terjadi pembagian hukum bagi bangsa Indonesia, meskipun pemerintah Hindia Belanda memberikan pilihan hukum bagi bangsa pribumi, dalam kasuskasus tertentu orang Indonesia tetap harus berpegang pada hukum perdata yang ditetapkan belanda, seperti dalam hukum kontrka atau jual beli. Hal ini disebabkan karena bangsa Eropa yang melakukan perjanjian dengan orang Indonesia ini bias melakukan pemaksaan bila saja dalam satu waktu penduduk pribumi tersebut tidak mau membayar hutangnya. Dalam hal ini masyarakat Eropa yang notabene memiliki pendidikan yang lebih tinggi justru lebih mengetahui bagaimna pentingnya suatu pencatatan (Ahmad Tholabi, 2013: 188). Suatu tinjauan lain yang dapat digunakan untuk melihat fenomena ini adalah suatu kenyataan bahwa norma hukum yang berasal dari suatu 
Negara memilki perbedaan-perbedaan substansial dari norma lain. Meskipun sama-sama memiliki fungsi untuk mengatur ketertiban masyarakat, norma hukum berbeda dalam hal sifat memaksanya. Sebagaimana diketahui norma-norma hukum lebih bersifat memaksa dan memiliki sanksi yang kuat bagi mereka yang melanggar, sehingga suatu tertib social justru lebih mampu dijamin oleh hukum daripada norma yang lain.

Dalam hal ini, dapat dinyatakan bahwa pencatatan perkawinan sejatinya berusaha menjawab aspek rasionalitas system birikrasi dan aspek kekinian perumusan hukum keluarga berusaha menjawab tantangan modernisasi. Karena secara rasional, pencatatan perkawinan dapat dikatakan konsisten dengan logika modernisme dan secara kekinian pencatatan perkawinan mewujudkan suatu trend NegaraNegara Muslim yang melakukan pembaharuan dalam hukum keluarga. Pencatatan perkawinan juga sebagai salah satu uapay untuk mewujudkan rumah tangga yang sakinnah, mawaddah, dan rahmah menjadi suatu keharusan dan keniscayaan. Untuk itu, Undang-Undang Nomor 1 Tahun 1974 tentang Perkawinan di Indonesia juga mengharuskan adanya pencatatan perkawinan bagi siapa saja yang melakukan perkawinan, meskipun pada hakikatnya tidak terdapat kesepakatan apakah pencatatan ini menjadi syarat sahnya suatu perkawinan atau tidak (Harotono Mardjono, 1997:96-97).

Hukum itu selalu bergantung pada ratio logis sehingga tidak diingkari adanya perubahan hukum disebabkan oleh perubahan ruang dan waktu. Disinilah, hukum termasuk hukum Islam di tuntut untuk selalu inovatif agar tidak ditinggalkan oleh masyarakatnya. Penetapan hukum Islam harus mengedepankan kemaslahatan mukallaf, sehingga keadilan dan kemanfaatan hukum akan lebih dirasakan oleh masyarakat. Karena, tujuan utama dari hukum Islam adalah untuk mewujudkan kemaslahatan umat. Sebagaimana yang 
diketahui bahwa pengabaian terhadap hukum pencatatan perkawinan dapat menimbulkan banyak kemudaratan terhadap status istri, anak, dan harta kekayaan perkawinan terutama berkaitan dengan upaya tertib administrasi kependudukan. Karena itu, akibat negatif tersebut harus dihilangkan demi kemaslahatan isteri, anak dan harta kekayaan perkawinan dengan tindakan yang bersifat preventif, kuratif dan antisipatif (Masruhan, 2013: 247).

Inti dari maqasid al-shari'ah adalah mencapai kemaslahatan dengan mewujudkan kebaikan dan menghindarkan keburukan. Seorang mukallaf akan bisa memperoleh kemaslahatan jika ia mampu menjaga lima hal, yaitu agama, jiwa, akal, keturunan, dan harta. Sebaliknya ia akan mendapatkan kemadaratan jika ia tidak bisa menjaga lima hal tersebut. Untuk mewujudkan kemaslahatan itu, menurut Menurut Syatibi, ada tiga tingkatan maqasid al-shari'ah, yaitu maqasid al-daruriyat, maqasid al-hajiyat, dan maqasid al tahsiniyat. Maqasid al-daruriyat merupakan kebutuhan yang harus ada yang tanpanya keselamatan umat manusia akan terancam baik di dunia maupun di akhirat. Ada lima hal yang termasuk dalam kategori ini, yaitu memelihara: agama, jiwa, kehormatan, keturunan, dan harta. Untuk memelihara lima hal pokok inilah syari'at Islam diturunkan. Maqasid al-hajiyat dimaksudkan untuk menghilangkan kesulitan dalam merealisasikan lima unsur tersebut dengan memberikan hukum rukhsah sehingga pemeliharaan terhadapnya menjadi lebih baik. Sedangkan maqasid al-tahsiniyat dimaksud kan agar manusia dapat melakukan yang terbaik untuk penyempurnaan lima unsur pokok. Pengabaian aspek ini akan menyebabkan ketidak sempurnaan upaya pemeliharaan lima unsur tersebut (AlSyatibi, 1975: 89).

Sangaji Jurnal Pemikiran Syariah dan Hukum 


\section{E. Kesimpulan}

Tujuan pencatatan perkawinan untuk mewujudkan ketertiban perkawinan mengandung relevansinya dengan maslahah (kemanfaatan) dalam pandangan Al-Syatibi. Relevansinya terletak pada perlindungan hak dan kewajiban masing-masing suami istri yaitu dalam hal perlindungan jiwa (hifdz al-nafs), melindungi hak nafkah, harta bersama, waris (hifdz al-mal), hak anak (hifdz al-nasl). Secara universal, hubungan pencatatan perkawinan dengan teori maslahah ini terlihat pada pengtamaan kebaikan dan menghindari keburukan. Pencatatan perkawinan ini mengandung maslahah dibandingkan mafsadah. Kemudian Hukum pencataatan perkawinan juga dilakukan dengan acuan maqasid as-syari'ah yang selalu mempertimbangkan ratio legis sehingga hukum yang dihasilkan dapat menjawab tuntutan perubahan waktu, tempat, keadaan dan kemaslahatan. 


\section{Daftar Pustaka}

Abdul kadir Muhammad, 2004. Hukum dan Penelitian Hukum.Cet. 1. Bandung: PT. Citra Aditya Bakti. Hal. 52.

Neng Djubedah, Pencatatan Perkawinan dan Perkawinan Tidak dicatat. Cet.1. Jakarta: Sinar Grafindo. 2010, hal. 207.

Mardjono Hartono, Menegakkan Syariat Islam dalam Konteks Keindonesiaan, cet 1. Bandung: Nizan. 1997,Hal. 96-97.

Ahmad Rajafi, Nalar Hukum Keluarga Islam di Indonesia, Yogyakarta: Istana Publishing, 2015. Hal. 151.

Masruhan, Pembaruan Hukum Pencatatan Perkawinan Di Indonesia Perspektif Maqasid Al-Shari'ah, Al-Tahrir, Vol. 13, No. 2 November 2013. Hal 247.

Zainuddin Ali, Hukum Perdata Islam di Indonesia, Jakarta: Sinar Grafindo, 2006, hlm. 26.

Ahmad Tholabi Kharlie, Hukum Keluarga Indonesia, Jakarta: Sinar Grafika, 2013Hal. 188.

Masud Khalid Muhammad, Filsafat Hukum Islam, Bandung : pustaka. 1996, hal 236.

Al-Syatibi, Al-Muwafaqat fi Usul al-Shari'ah, Juz IV Beirut: Dar al Ma'rifah, 1975. Hal 89.

Sangaji Jurnal Pemikiran Syariah dan Hukum 